\title{
EFFECT OF COLLECTOR Size ON CENTER PIVOT WATER DEPTH CATCH
}

\author{
D. H. Rogers, J. P. Aguilar, G. A. Clark, S. W. Wiens
}

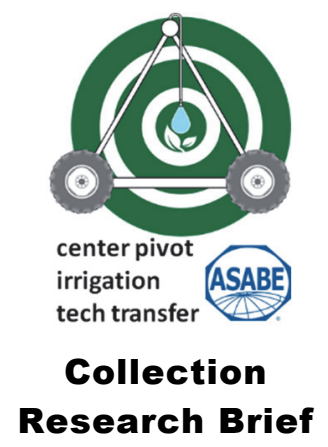

\begin{abstract}
The ASABE standard on uniformity testing of a center pivot system contains specifications on the collector size to measure the applied water depth. The standard was developed before many of the current sprinkler application devices were developed. A study was conducted to compare the catch depths of five collector sizes (opening diameters of 5.5, 10, $14.8,20$, and $27.4 \mathrm{~cm}$, referenced as C2, C4, C6, C8, and C10) for three types of sprinkler application devices: spinning plate, fixed plate, and wobbling plate sprinkler systems using four $5 \times 5$ Latin squares. Each collector's water depth was measured and statistically analyzed. Two analysis of variance (ANOVA) tests of the collector size effect were reported. Past experimental results were also compared to this experiment's results, which generally reaffirms the difficulty of consistently measuring irrigation application depth within the practical range of collector sizes. Based on sprinkler application devices, fixed plate tends to have a more consistent depth caught compared to wobbling plate and spinning plate. If the ideal collector size selection was based on minimum variability of depth measurements, then either C6 or C4 collectors could be used. This study showed that within the range of sizes used, collector size does not substantially affect measurement of application depths for center pivot sprinkler systems. Despite the challenging task, measurement is probably within 5\% if an appropriate number of collectors are used.
\end{abstract}

Keywords. Catch can collector size, Center pivot irrigation, Sprinkler packages, Uniformity.

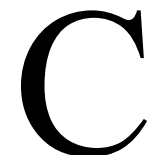
enter pivot irrigation systems are used on over $90 \%$ of the irrigated land in Kansas (Rogers and Aguilar, 2017) and over 50\% in the United States (USDA, 2013). A variety of reasons related to the adaptability of the systems to a wide variety of field conditions, crops, cropping systems, labor, water supplies and ultimately favorable economics, along with the capability of efficiently and uniformly applying water, have contributed

The authors have paid for open access for this article. This work is licensed under a Creative Commons AttributionNonCommercial-NoDerivatives 4.0 International License https://creative commons.org/licenses/by-nc-nd/4.0/

Submitted for review in January 2019 as manuscript number NRES 13311; approved for publication as a Research Brief and as part of the Center-Pivot Irrigation Tech Transfer Collection by the Natural Resources \& Environmental Systems Community of ASABE in August 2019.

The authors are Danny H. Rogers, Professor and Extension Agricultural Engineer, Jonathan P. Aguilar, Associate Professor and Extension Irrigation Specialist, Gary A. Clark, Professor and Senior Associate Dean for the College of Engineering, and Scott W. Wiens, Completed MS Student, Department of Biological and Agricultural Engineering, Kansas State University, Manhattan, Kansas. Corresponding author: Jonathan Aguilar, Kansas State University, Southwest Research and Extension Center, 4500 E. Mary St., Garden City, KS 67846; phone: 620-275-9164; e-mail: jaguilar@ ksu.edu. to the conversion to center pivot irrigation systems from surface irrigation systems or the expansion of irrigation into previously unirrigated cropland areas.

Quantification of the uniformity of water application by sprinkler systems was pioneered by Christiansen (1942) which was before the invention of center pivot sprinkler irrigation systems. The adaption of Christiansen's coefficient of uniformity (CU) concept to center pivot systems was accomplished by weighting the individual application depths along the center pivot lateral relative to the area served at that location (Heermann and Hein, 1968). This adaptation of the $\mathrm{CU}$ equation is the basis for the ASABE standard, Test Procedure for Determining the Uniformity of Water Distribution of Center Pivot and Lateral Move Irrigation Machines Equipped with Spray or Sprinkler Nozzles, for quantifying the water application uniformity for center pivot irrigation systems (ASABE S436.1, 2007b).

In addition to ASAE S436.1, ASAE S398.1 (2007a), Procedure for Sprinkler Testing and Performance Reporting, is a standard to quantify the performance of individual sprinkler devices. The ASAE S398.1 standard does not specify the collector size, only that they should be identical and no water can splash in or out. ASAE S436.1 expands the specification to include height of the collector and the minimum entrance diameter, which is to be no less than $60 \mathrm{~mm}$. 
Schneider (2000) noted that the use of collectors is the common method of measuring irrigation application depths but cautioned against using small catch cans for use on uniformity studies of spray irrigation systems. Marek and Howell (1987) compared the catches of seven different collectors to a separatory funnel gage used in their previous research and found that the larger diameter collectors had less variability than smaller diameter collectors. They indicated a diameter of $75 \mathrm{~mm}$ was needed to measure within $+2 \%$ of the separatory funnel gage.

Clark et al. (2006a) used $100 \mathrm{~mm}$ Irrigages (Clark et al., 2004) to measure the application uniformity of three low pressure center pivot nozzle devices and compared the results to a $430 \mathrm{~mm}$ pan collector. They found that the $100 \mathrm{~mm}$ Irrigages under-reported the application depths as compared to the pans. The test was repeated the following year for the same system but at a different location within the field; this time the Irrigages collected higher application depths than the pans, leading to the conclusion that the diameter size of the Irrigage used was too small for the low-pressure application devices of the irrigation system. Clark et al. (2006b) conducted a lab study to determine the minimum collector diameter for spray systems using diameters from 52 to 780 $\mathrm{mm}$ and compared the results to approximately square collectors with 198 by $211 \mathrm{~mm}$ opening. The results from the collections from six different spray devices were highly variable, again leading to a conclusion that consistently measuring water application depths from low pressure spray devices is a challenging task.

The goal of this study was to evaluate the accuracy and variability of measured irrigation water application depths of various collector diameter sizes for three types of water application devices: fixed plate, spinning plate and wobbling plate sprinkler devices under Southwest Kansas production field conditions. Five collector devices with unique diameters were positioned under three different center pivot irrigation systems in a $5 \times 5$ Latin square arrangement to measure the application depth. Statistical analysis of the measured data was used to identify the ideal collector size associated with each of the three application device types.

\section{Procedure}

Field evaluations were conducted at three farms near Garden City, Kansas, each equipped with one of the target application devices. Site 1 was equipped with spinning plate devices, represented by Nelson A300 Accelerator sprinklers (Walla Walla, Wash.) with Nelson $69 \mathrm{kPa}$ pressure regulators. Sprinklers were positioned approximately $1.5 \mathrm{~m}$ above ground surface. At the site 1 test zone, nozzle sizes included two Nelson \#28 (5.56 mm; 28/128 in.), and a \#29 (5.75 mm; $29 / 128 \mathrm{in}$.) with a sprinkler spacing of $3.05 \mathrm{~m}$. Site 2 was equipped with fixed plate devices, represented by Senninger LDN spray sprinklers (Clermont, Fla.) with D3000 blue stream deflector plates and \#29 (11.5 mm; 29/64 in.) nozzle sizes, and Senninger $104 \mathrm{kPa}$ pressure regulators. Sprinklers were positioned approximately $1.8 \mathrm{~m}$ above ground surface and spaced at $1.5 \mathrm{~m}$. Site 3 was equipped with wobbling plate devices, represented by Senninger I-Wobs with LA9 stream deflection pads, $6.55 \mathrm{~mm}\left(33 / 128^{\text {th }}\right.$ in. $)$ nozzles, and Senninger $83 \mathrm{kPa}$ pressure regulators. Sprinklers were positioned approximately $2.3 \mathrm{~m}$ above ground and were on a 2.3 $\mathrm{m}$ spacing. Weather conditions during each field test are reported below (table 1) and are typical for southwestern Kansas during the summer months. The wobbling plate system was tested early in the morning when the air temperature was cool and the humidity was high. Both the spinning plate and fixed plate systems were tested in the afternoon. All tests met the ASAE S436.1 guideline for the maximum wind speed of less than $5 \mathrm{~m} / \mathrm{s}$ but only the fixed plate test met the guideline recommendations of wind speed being less than $1 \mathrm{~m} / \mathrm{s}$.

Twenty test collectors for each of the five diameters were constructed with opening diameters of $5.5,10,14.8,20$, and $27.4 \mathrm{~cm}$, referenced as $\mathrm{C} 2, \mathrm{C} 4, \mathrm{C} 6, \mathrm{C} 8$, and $\mathrm{C} 10$, respectively. All collectors had a height of $20.3 \mathrm{~cm}$ and the opening edges were beveled to create a sharp-edge inner lip. Additional construction details are available in Wiens (2010).

SAS 9.2 (Cary, N.C.) was used to generate the design of the collector arrangement in the field. Four Latin square replicates were used for each sprinkler test. Figures 1 and 2 show the details of the generalized test location within the

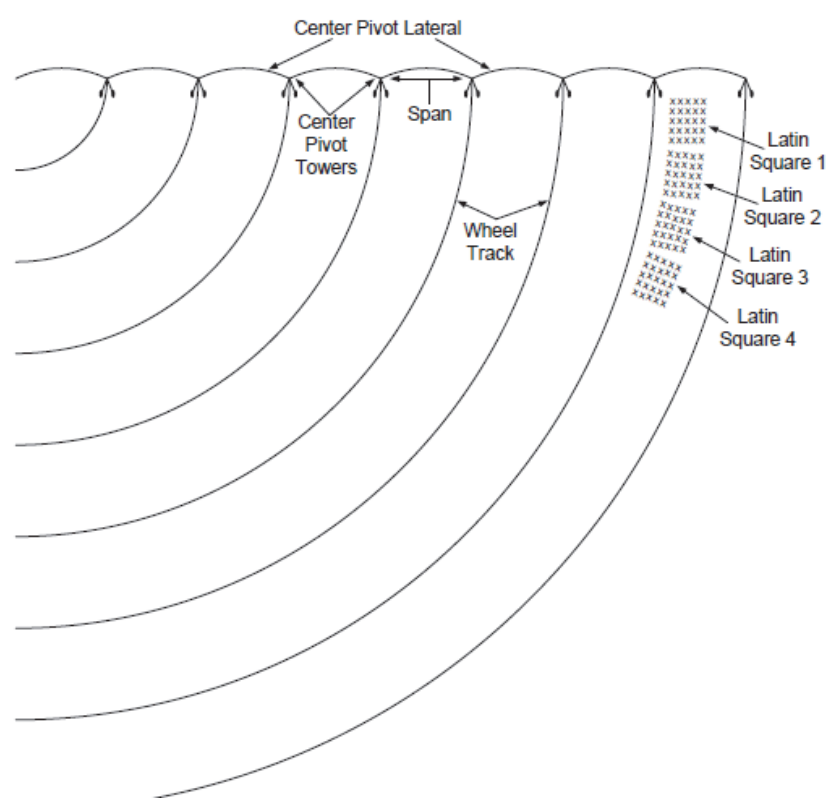

Figure 1. Center pivot irrigation system and location of Latin square field site.

Table 1. Weather conditions of the 2009 field tests.

\begin{tabular}{|c|c|c|c|c|c|c|}
\hline System & Date & $\begin{array}{l}\mathrm{T}^{[\mathrm{a}]} \\
\left({ }^{\circ} \mathrm{C}\right) \\
\end{array}$ & $\begin{array}{c}\text { Heat Index } \\
\left({ }^{\circ} \mathrm{C}\right)\end{array}$ & $\begin{array}{c}\mathrm{RH}^{[\mathrm{a}]} \\
(\%)\end{array}$ & $\begin{array}{c}\text { Wind Speed Max } \\
(\mathrm{km} / \mathrm{h})\end{array}$ & $\begin{array}{c}\text { Wind Speed Avg. } \\
(\mathrm{km} / \mathrm{h})\end{array}$ \\
\hline Spinning plate & 15 July 2009 & 31.9 & 44 & 81 & 23 & 14.0 \\
\hline Fixed plate & 5 August 2009 & 34.8 & 45.5 & 66 & 13 & 2.6 \\
\hline Wobbling plate & 15 July 2009 & 24.0 & 27.1 & 100 & 12 & 4.5 \\
\hline
\end{tabular}

[a] $\mathrm{T}=$ air temperature, $\mathrm{RH}=$ relative humidity. 


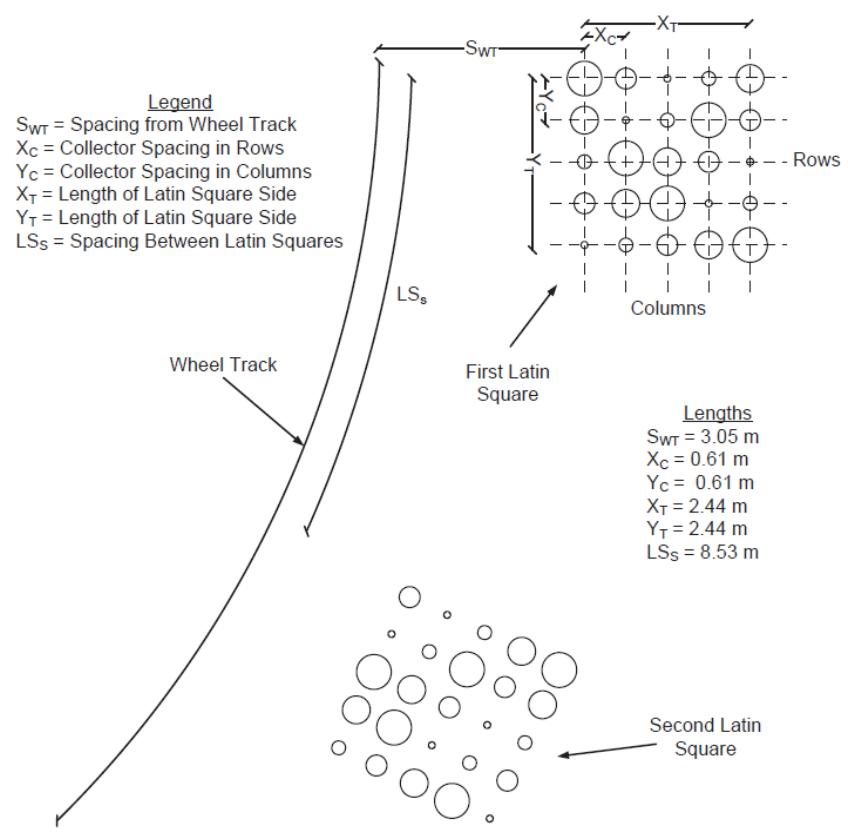

Figure 2. Two Latin squares with the collector spacing, columns, and rows labeled.

field and example collector positions within the Latin square experimental design.

The tests were conducted under acceptable weather conditions and the average application depths met the minimum depth specified by ASAE S436.1 standard for uniformity of center pivot irrigation systems. Evaporation losses were minimized by measuring the collected volumes as soon as the collectors stopped receiving water from the irrigation event. Collected water was measured using a graduated cylinder. Measured volumes were converted to an application depth by dividing the volume by the collector surface area.

The SAS 9.2 "Proc Means" command was used to determine the means and standard deviations of the depth measurements for the different collectors, columns and squares. An analysis of variance (ANOVA) of the depths was created using the "Proc Mixed" command for the collector sizes, since this accounted for both fixed (collector size, column and row) and random (Latin square) effect factors in the model. If the ANOVA showed there was a significant effect of collector size on depth, then the collector size measurements were compared.

The ANOVA also examined the variability of measured depth of each collector size. The significance of the column effect on measured depth was determined for each test. If there was significance, then the measured depths were adjusted to eliminate the column effect. After adjustments, the standard deviation of the measured depth data was calculated and used to develop an ANOVA of whether collector size had an effect on the variability of the measured depths. If size was significant, then a comparison between collector sizes was made.

In addition, the $95 \%$ confidence interval was created for each collector size and used to estimate accuracy of a depth measurement for a given number of collectors.

\section{RESULTS AND DISCUSSION COllector Size, COLUMN, AND SQuare Measured DePTHS}

Catch can application depths measured with the different collector sizes on the three different types of center pivot irrigation sprinkler packages were analyzed to study the effect of collector size on measured water depth. The means and standard deviations for the combination of all catches for each system test are shown in table 2. The FP average applied depth was much larger than SP and WP values, making the standard deviation of FP large but still with a comparable amount of variability (table 3 ).

There was no statistical difference in the mean applied depth for the spinning plate (SP) sprinkler (table 3). The largest measurement difference between containers for SP was $0.05 \mathrm{~cm}$, or about $3 \%$ of the applied depth. The C6 container had the lowest $\mathrm{CV}$ value.

Position of the catch container in each column (see fig. 2) was statistically different (table 3 ) for SP. This is likely due to the position of each column relative to the application depth applied at that position which is influenced by the combined depth of water applied at a location by the overlapping streams of water from adjacent sprinklers. There were also differences in the water application depth of each square of collectors (table 3 ) with a decreasing amount of depth with each successive square. The reason for this change in depth measurement is unclear as the variability of the measurements within the squares was consistent across all squares.

Fixed plate (FP) results from table 3 show there was a statistical difference between measured collector depths with $\mathrm{C} 10$ having the lowest value. The $\mathrm{CV}$ associated with the various collector sizes was similar and ranged from 0.09 to 0.106 .

Statistical differences associated with columns and squares for FP were also significant. In general, inner column catch depths were lower than outer column catch depths as discussed similar to the SP results. Measured depth from the squares were also statistically different, which would be unexpected, since the tests were conducted with no noted changes in weather or operating conditions and measurements were taken as soon as the application depth passed each square wobbling plate (WP) results, shown in table 3, indicate there were statistical differences between the collector sizes with $\mathrm{C} 6$ having the greatest measured catch. The

Table 2. Means and standard deviation of each sprinkler system combined across collector diameter sizes.

\begin{tabular}{|c|c|c|c|c|c|c|}
\hline System & $\begin{array}{c}\text { Applied Depth } \\
(\mathrm{cm})\end{array}$ & $\begin{array}{c}\text { Nominal Depth } \\
(\mathrm{cm})\end{array}$ & $\begin{array}{l}\text { Lower } 95 \% \text { Mean } \\
\text { Confidence Level }\end{array}$ & $\begin{array}{l}\text { Upper 95\% Mean } \\
\text { Confidence Level } \\
\end{array}$ & $\begin{array}{l}\text { St. Dev. } \\
(\mathrm{cm})\end{array}$ & $\mathrm{CV}$ \\
\hline Spinning plate & 1.49 & 1.52 & 1.46 & 1.51 & 0.11 & 0.07 \\
\hline Fixed plate & 5.11 & 5.08 & 5.01 & 5.21 & 0.51 & 0.10 \\
\hline Wobbling plate & 2.27 & 2.54 & 2.23 & 2.31 & 0.21 & 0.09 \\
\hline
\end{tabular}


Table 3. Means analysis results for the spinning plate (SP), fixed plate (FP), and wobbling plate (WP) sprinklers organized by container sizes, relative location in the Latin square, and Latin square number.

\begin{tabular}{|c|c|c|c|c|c|c|}
\hline \multirow[b]{2}{*}{ Treatment } & \multicolumn{2}{|c|}{ Spinning Plate (SP) Nozzle } & \multicolumn{2}{|c|}{ Fixed Plate (FP) Nozzle } & \multicolumn{2}{|c|}{ Wobbling Plate (WP) Nozzle } \\
\hline & Mean Depth ${ }^{[a]}$ & & Mean Depth ${ }^{[a]}$ & & Mean Depth ${ }^{[a]}$ & \\
\hline Container & $(\mathrm{cm})$ & $\mathrm{CV}$ & $(\mathrm{cm})$ & $\mathrm{CV}$ & $(\mathrm{cm})$ & $\mathrm{CV}$ \\
\hline $\mathrm{C} 2$ & $1.51 \mathrm{a}$ & 0.084 & $5.23 \mathrm{a}$ & 0.103 & $2.30 \mathrm{ab}$ & 0.148 \\
\hline $\mathrm{C} 4$ & $1.48 \mathrm{a}$ & 0.073 & $5.04 \mathrm{ab}$ & 0.094 & $2.23 b$ & 0.061 \\
\hline C6 & $1.51 \mathrm{a}$ & 0.040 & $5.19 \mathrm{a}$ & 0.106 & $2.35 \mathrm{a}$ & 0.091 \\
\hline $\mathrm{C} 8$ & $1.47 \mathrm{a}$ & 0.078 & $5.22 \mathrm{a}$ & 0.093 & $2.26 \mathrm{ab}$ & 0.059 \\
\hline $\mathrm{C} 10$ & $1.46 \mathrm{a}$ & 0.083 & $4.85 \mathrm{~b}$ & 0.090 & $2.22 \mathrm{~b}$ & 0.055 \\
\hline \multicolumn{7}{|c|}{ Column Number } \\
\hline 1 (Inner) & $1.45 \mathrm{c}$ & 0.060 & $4.91 \mathrm{~cd}$ & 0.069 & $2.20 \mathrm{bc}$ & 0.166 \\
\hline 2 & $1.47 \mathrm{bc}$ & 0.067 & $4.77 \mathrm{~d}$ & 0.076 & $2.18 \mathrm{c}$ & 0.048 \\
\hline 3 & $1.42 \mathrm{c}$ & 0.060 & $5.12 \mathrm{bc}$ & 0.095 & $2.35 \mathrm{a}$ & 0.029 \\
\hline 4 & $1.53 \mathrm{ab}$ & 0.095 & $5.26 \mathrm{ab}$ & 0.102 & $2.32 \mathrm{ab}$ & 0.048 \\
\hline 5 (Outer) & $1.55 \mathrm{a}$ & 0.035 & $5.48 \mathrm{a}$ & 0.091 & $2.31 \mathrm{ab}$ & 0.085 \\
\hline \multicolumn{7}{|c|}{ Square Number } \\
\hline 1 & $1.54 \mathrm{a}$ & 0.066 & $5.45 \mathrm{a}$ & 0.099 & $2.33 \mathrm{a}$ & 0.058 \\
\hline 2 & $1.52 \mathrm{ab}$ & 0.070 & $5.37 \mathrm{a}$ & 0.076 & $2.21 \mathrm{~b}$ & 0.063 \\
\hline 3 & $1.47 \mathrm{~b}$ & 0.059 & $4.78 \mathrm{~b}$ & 0.075 & $2.39 \mathrm{a}$ & 0.126 \\
\hline 4 & $1.41 \mathrm{c}$ & 0.066 & $4.82 b$ & 0.065 & $2.16 \mathrm{~b}$ & 0.060 \\
\hline
\end{tabular}

[a] Sprinkler type measured depths with the same letter are not different at the $95 \%$ significance level.

$\mathrm{CV}$ of $\mathrm{C} 2$ was higher than for the other collectors, which implies less confidence in the accuracy of individual measurements for that collector size as compared to the other options.

Statistical differences also occurred for columns and squares for WP. In general, inner columns collector depths were less then outer collector depths as discussed for SP collectors. The squares were also statistically different, which was unanticipated.

The results of the Proc Mixed test of measured depths identify measurement variability (table 4). Each of the sprinkler types had measured variation with regards to column location as discussed previously. The collectors under the FP sprinklers also had a significant measurement variability associated with row location and collector size. Collector size was not a factor for SP and WP sprinklers in this test.

\section{COLlector Size COMPARISON USING THE Measured Mean DePTHS}

Table 5 shows the statistical analysis results from Proc Mixed for the comparison of measured depths for FP since it was the only sprinkler type that showed collector size had a significant effect (table 3) on measured depth. However, there was no consistent effect of collector size on the recorded catch (i.e. increasing or decreasing with size) with $\mathrm{C} 10$ having the lowest catch, then $\mathrm{C} 4$ and then $\mathrm{C} 2$ and $\mathrm{C} 8$ having similar catch. This may be further illustrating the difficulty of accurately measuring catch for serrated deflection pads with fixed plate sprinklers.

Since the actual water application depth is not known, the ideal collector size cannot be determined from this study. As noted in table 3, C10, the largest collector size, had the lowest measured depth result. While large collector diameter is associated with increased accuracy, acceptance of the C10 average depth as the closest to the true actual applied depth, would ignore the observation that the combined estimated depth from C2, C6, and C8 (60 observations that were very consistent) were greater.
Table 4. Proc Mixed results for the collector size effect on measured depth for the spinning plate, fixed plate, and wobbling plate systems. Sprinkler Degrees of

\begin{tabular}{|c|c|c|c|c|c|}
\hline Type & Source & Freedom & F Value & p-Value & Significance ${ }^{[\mathrm{a}]}$ \\
\hline \multirow{3}{*}{$\begin{array}{c}\text { Spinning } \\
\text { plate }\end{array}$} & Row & 84 & 1.12 & 0.3528 & NS \\
\hline & Column & 84 & 8.87 & $<0.0001$ & $* * *$ \\
\hline & Collector size & 84 & 1.47 & 0.2187 & NS \\
\hline \multirow{3}{*}{ Fixed plate } & Row & 84 & 2.62 & 0.0405 & ** \\
\hline & Column & 84 & 18.66 & $<0.0001$ & $* * *$ \\
\hline & Collector size & 84 & 6.17 & 0.0002 & $* * *$ \\
\hline \multirow{3}{*}{$\begin{array}{c}\text { Wobbling } \\
\text { plate }\end{array}$} & Row & 84 & 0.34 & 0.8518 & NS \\
\hline & Column & 84 & 3.63 & 0.0089 & $* * *$ \\
\hline & Collector size & 84 & 1.79 & 0.1386 & NS \\
\hline
\end{tabular}

[a] NS indicates collectors are not significantly different,

* indicates collectors different at $90 \%$ significance,

** indicates collectors different at $95 \%$ significance, and

$* * *$ indicates collectors different at $99 \%$ significance.

\section{COLLECTOR SIZE COMPARISON USING THE VARIABILITY OF THE MEASURED DEPTHS}

The final statistical test was the Proc Mixed test on the level of variability (SD) of the measured depth for the various collector sizes for each of the sprinkler types. In this test, the test model adjusted the raw data to eliminate the column effect. The results, shown in table 6, show only SP had significant differences in the variability of the measured depths. Therefore, SP's SD values were Proc Mixed tested for significance. The results are shown in table 7, for $99 \%$ and $90 \%$ confidence levels. At 99\%, C6 had lower variability than C2 or $\mathrm{C} 10$. At $90 \%, \mathrm{C} 2$ had lower variability than C4, C6 was different than $\mathrm{C} 8$, and $\mathrm{C} 6$ different than $\mathrm{C} 10$.

Table 5. Proc Mixed comparison test of the measured depths for the fixed plate sprinkler.

\begin{tabular}{|c|c|c|c|}
\hline & Treatment $^{[\mathrm{a}]}$ & Mean $(\mathrm{cm})$ & $95 \%$ Significance Grouping ${ }^{[\mathrm{b}]}$ \\
\hline & $\mathrm{C} 2$ & 5.23 & $\mathrm{~A}$ \\
\hline & $\mathrm{C} 4$ & 5.04 & B \\
\hline & C6 & 5.19 & $\mathrm{AB}$ \\
\hline & $\mathrm{C} 8$ & 5.22 & $\mathrm{AB}$ \\
\hline & $\mathrm{C} 10$ & 4.85 & $\mathrm{C}$ \\
\hline & \multicolumn{3}{|c|}{$\begin{array}{l}\mathrm{C} 2, \mathrm{C} 4, \mathrm{C} 6, \mathrm{C} 8 \text {, and } \mathrm{C} 10 \text { have opening diameters of } 5.5,10,14.8,2 \mathrm{C} \\
\text { and } 27.4 \mathrm{~cm} \text {, respectively. }\end{array}$} \\
\hline & \multicolumn{3}{|c|}{$\begin{array}{l}\text { Treatments with the same letter are not significantly different at the } \\
95 \% \text { level. }\end{array}$} \\
\hline
\end{tabular}


Table 6. Proc Mixed test of the collector size effect on variability of measure depth.

\begin{tabular}{lcccc}
\hline \multicolumn{1}{c}{ Sprinkler Type } & $\begin{array}{c}\text { Degrees of } \\
\text { Freedom }\end{array}$ & F Value & p-Value & Significance $^{[\mathrm{a}]}$ \\
\hline Spinning plate & 12 & 3.43 & 0.0432 & $* *$ \\
Fixed plate & 12 & 0.10 & 0.9817 & $\mathrm{NS}$ \\
Wobbling plate & 12 & 1.09 & 0.4061 & $\mathrm{NS}$ \\
\hline
\end{tabular}

[a] NS indicates collectors are not significantly different, and

** indicates collectors different at $95 \%$ significance.

\section{ACCURACY OF WATER DePTH MEASUREMENT FOR A GIVEN NUMBER OF COLlectors}

The estimate of the standard deviation for a given collector size can be used to calculate the accuracy of a measured mean water application depth for a given number of collectors. The data collected was used in the following graphs to estimate (at 95\% confidence interval) the range of depth measurement that would be needed to achieve desired depth. Since this data set consists of measurements from only one system for each type of sprinkler operating under the weather and operating conditions during the test period, the results should not be extended to other systems equipped with similar sprinkler types. However, the results do indicate the use of additional collectors would improve the accuracy of measurement.

Figure 3 shows the range of the water depth as a measurement value interval or percentage for the spinning plate system for collector numbers up to 20 for the mean water depth of $1.49 \mathrm{~cm}$ from this test. Since the C2 and C10 collectors had the same level of variability, their accuracy lines are identical. C6 collectors in this study had the lowest variability as compared to the other collector sizes. So, for example, five C6 collectors would have a water depth interval percent of approximately $3 \%$, while five $\mathrm{C} 2$ or C 10 collectors would be estimated at $6 \%$. Figure 3 could also be read that it would take ten $\mathrm{C} 4$ or eleven $\mathrm{C} 8$ collectors to arrive at the same accuracy as five C6 collectors at 3\%. While this again seems an unlikely generalization, this is the outcome of this data set.

The water depth measurement accuracy of the fixed plate system was very similar for all collector sizes studied (fig. 4) which was unanticipated. As noted previously, it was expected that the distinct water streams produced by fixed plate sprinklers have high variability especially with the smaller collector diameters. The mean depth estimates show more similarity for the different collector sizes than either of the spinning plate or wobbling plate systems.

Table 7. Comparison test of the measured depth variability for the spinning plate system.

\begin{tabular}{cccc}
\hline $\begin{array}{c}\text { Collector } \\
\text { Size }\end{array}$ & $\begin{array}{c}\text { Estimated Standard } \\
\text { Deviation }(\mathrm{cm})\end{array}$ & $\begin{array}{c}99 \% \text { Significance } \\
\text { Grouping }^{[\mathrm{b}]}\end{array}$ & $\begin{array}{c}90 \% \text { Significance } \\
\text { Grouping }\end{array}$ \\
\hline $\mathrm{C} 2$ & 0.100 & $\mathrm{~A}$ & $\mathrm{~A}$ \\
$\mathrm{C} 4$ & 0.0687 & $\mathrm{AB}$ & $\mathrm{BC}$ \\
$\mathrm{C} 6$ & 0.0477 & $\mathrm{~B}$ & $\mathrm{~B}$ \\
$\mathrm{C} 8$ & 0.0785 & $\mathrm{AB}$ & $\mathrm{AC}$ \\
$\mathrm{C} 10$ & 0.0997 & $\mathrm{~A}$ & $\mathrm{~A}$ \\
\hline [a] & $\mathrm{C} 2, \mathrm{C} 4, \mathrm{C} 6, \mathrm{C} 8$, and C10 have opening diameters of 5.5, 10, 14.8, 20, \\
and 27.4 cm, respectively. & \\
[b] & \\
Treatments with the same letter are not significantly different at the \\
noted significance level.
\end{tabular}

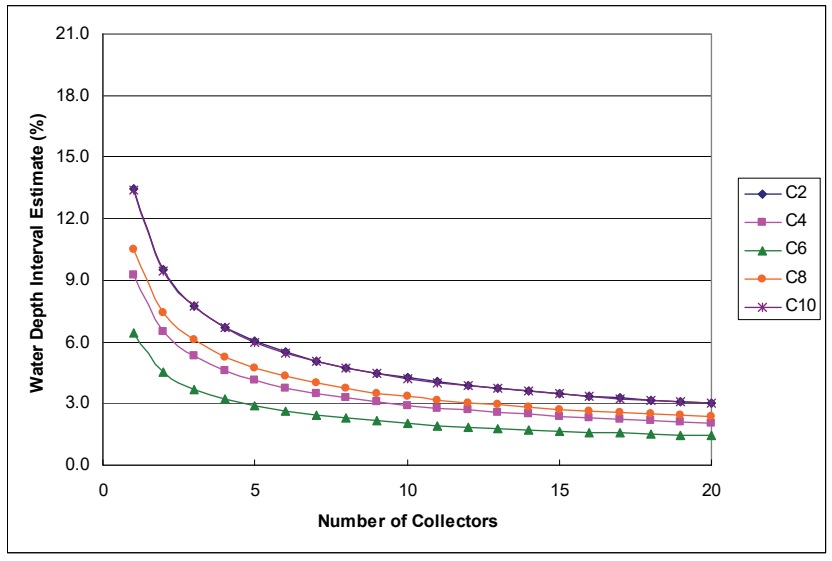

Figure 3. Normalized estimate of measurement accuracy (\%) based upon collector size and number of collectors for the spinning plate system. C2, C4, C6, C8, and $\mathrm{C} 10$ have opening diameters of 5.5, 10, 14.8, 20 , and $27.4 \mathrm{~cm}$, respectively.

The results for the wobbling plate sprinklers indicate a more expected outcome of increased accuracy for larger diameter collectors as shown in figure 5, even though this is not consistent. For example, the $\mathrm{C} 4$ collector had similar accuracy as compared to $\mathrm{C} 8$ and $\mathrm{C} 10$ but $\mathrm{C} 6$ was less accurate than $\mathrm{C} 4$.

\section{CONCLUSION}

Measured depth and variability of three distinct sprinkler application devices were compared for five different catch can collector sizes using a replicated Latin square study design. The collectors were labeled as C2, C4, C6, C8, and C10 with diameters of $5.5,10.0,14.8$, and $20.0 \mathrm{~cm}(2.19,3.92$, 5.81 , and $7.87 \mathrm{in}$.).

The C6 collector measured the largest water depths for the Spinning Plate (SP) and the Wobbling Plate (WP) sprinkler systems, while the $\mathrm{C} 2$ collector measured the greatest depths for the Fixed Plate (FP) sprinkler system. The C10 collectors measured the lowest water depth for all three sprinkler systems. The larger collector sizes measured the same variability of measured depths as the smaller collector sizes for the SP and FP systems. No general trend could be

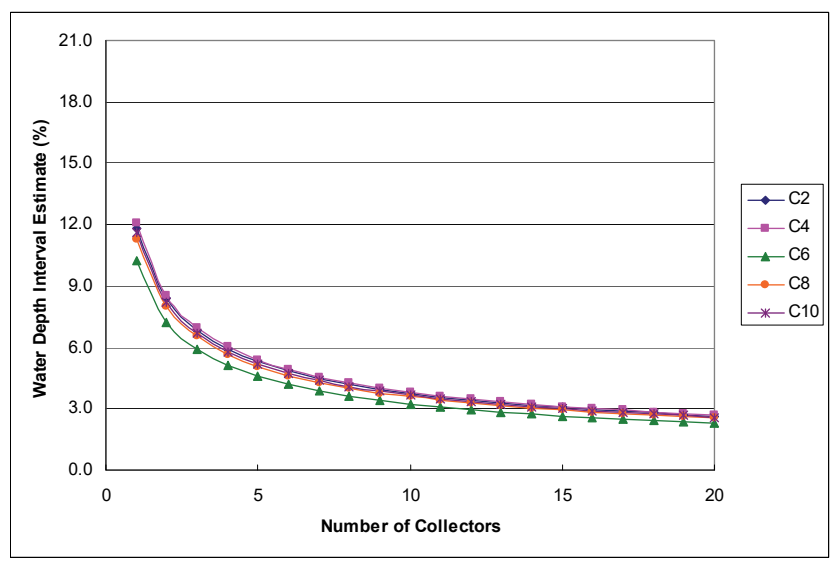

Figure 4. Normalized estimate of measurement accuracy (\%) based upon collector size and number of collectors for the fixed plate system. $\mathrm{C2}, \mathrm{C} 4, \mathrm{C} 6, \mathrm{C} 8$, and $\mathrm{C} 10$ have opening diameters of 5.5, 10, 14.8, 20, and $27.4 \mathrm{~cm}$, respectively. 


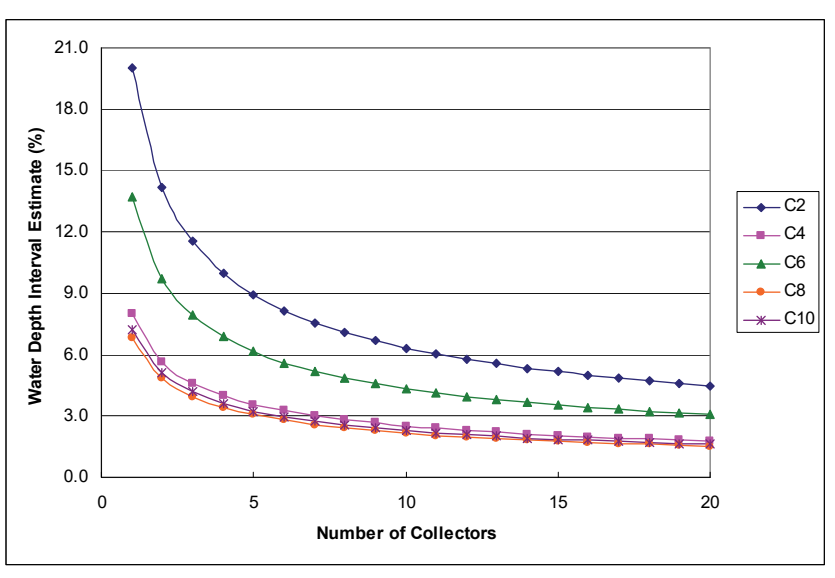

Figure 5. Normalized estimate of measurement accuracy (\%) based upon collector size and number of collectors for the wobbling plate system. C2, C4, C6, C8, and $\mathrm{C} 10$ have opening diameters of 5.5, 10, 14.8, 20 , and $27.4 \mathrm{~cm}$, respectively.

observed on the measured depth variability in relation to the collector size for the WP system, and interestingly, C4, C8, and $\mathrm{C} 10$ collectors had similar levels of measurement variability. The larger collector sizes were observed to record lower measured depth variability for the fixed plate system but the variability was consistent across all collector sizes.

Previous studies had indicated difficulty in accurately measuring the application depth of FP systems using collectors with small diameters as compared with other sprinkler types. An ANOVA of the measured depths showed that the latter expectation was upheld as collector size was not a significant factor in determining the mean water depth for SP and WP systems. However, for the FP system, collector size was significant at the $95 \%$ level.

The comparison test of the collector sizes for the FP system indicated that the $\mathrm{C} 2$ and $\mathrm{C} 4$ collectors measured significantly different depths and the $\mathrm{C} 10$ collector was significantly different from all other collectors.

The variability of the measured depths indicated significant differences for the SP system but not for FP and WP systems. The C6 collector had lower depth measurement variability ( $90 \%$ significance) than the $\mathrm{C} 2, \mathrm{C} 8$, and $\mathrm{C} 10$ collectors and the $\mathrm{C} 4$ collector had measured variability that was significantly lower than the variability of $\mathrm{C} 2$ and $\mathrm{C} 10$ measured depths.

If the ideal collector size selection was based on minimum variability of depth measurements, then either $\mathrm{C} 6$ or $\mathrm{C} 4$ collectors could be used. The measurement variability of C6 was numerically lower than the $\mathrm{C} 4$ but not statistically significantly different. Though not significant, C4, C8, and C10 had the lowest variability of measured depths for the WP system. A surprising outcome for this study, all collector sizes measured similar levels of variability of depth measurements for the FP system. The inconsistency of the variability and/or accuracy of the measurements between the sprinkler types regardless of the collector size indicate that accurate measurement of application depths for center pivot sprinkler systems is a challenging task but one is probably within $5 \%$ if an appropriate number of collectors are used.

\section{ACKNOWLEDGEMENT}

This study was supported in part by the Ogallala Aquifer Project 58-6209-6-31.

\section{REFERENCES}

ASABE Standards. (2007a). S398.1: Procedure for sprinkler testing and performance reporting. St. Joseph, MI: ASABE.

ASABE Standards. (2007b). S436.1: Test procedure for determining the uniformity of water distribution of center pivot and lateral move irrigation machines equipped with spray or sprinkler nozzle. St. Joseph, MI: ASABE.

Christiansen, J. E. (1942). Irrigation by sprinkling. Agr. Exp. Sta. Bulletin 670. Berkeley: University of California.

Clark, G. A., Dogan, E., Rogers, D. H., \& Martin, V. L. (2006a). Evaluation of IrriGage collectors to measure irrigation depths from low pressure sprinklers. Appl. Eng. Agric., 22(1), 63-72. https://doi.org/10.13031/2013.20193

Clark, G. A., Rogers, D. H., \& Alam, M. (2006b). Evaluation of collector size for low pressure, fixed-plate sprinklers for center pivots. Contribution No. 07-18-A. Proc. Technical Conf. of the Irrigation Association.

Clark, G. A., Rogers, D. H., Dogan, E., \& Krueger, R. (2004). The IrriGage: A non? Evaporating in? Field precipitation gage. Appl. Eng. Agric., 20(4), 463-466. https://doi.org/10.13031/2013.16494

Heermann, D. F., \& Hein, P. R. (1968). Performance characteristics of self-propelled center-pivot sprinkler irrigation system. Trans. ASAE, 11(1), 11-15. https://doi.org/10.13031/2013.39320

Marek, T. H., \& Howell, T. A. (1987). Evaluation of sprinkler application collection devices. ASAE Paper No. 87-2592. St. Joseph, MI: ASAE.

Rogers, D. H., \& Aguilar, J. (2017). Kansas irrigation trends. Irrigation management series. MF-2849 (revised). Manhattan: Kansas State Research and Ext.

Schneider, A. D. (2000). Efficiency and uniformity of the LEPA and spray sprinkler methods: A review. Trans. ASAE, 43(4), 937-944. https://doi.org/10.13031/2013.2990

USDA. (2013). Farm and ranch irrigation survey. Washington, DC: USDA. Retrieved from https://www.agcensus.usda.gov/Publications/2012/Online_Resour ces/Farm_and_Ranch_Irrigation_Survey/fris13_2_028_028.pdf

Wiens, S. W. (2010). Collector size effect on the measurement of applied water depth for irrigation systems. MS thesis. Manhattan: Kansas State University, Department of Biological and Agricultural Engineering. 